\title{
Financial Market Development and Risk of Commercial Banking Operation in Vietnam
}

\author{
HOANG CONG GIA KHANH \\ University of Economics and Law - hcgk@uel.edu.vn \\ TRAN HUNG SON \\ University of Economics and Law - sonth@uel.edu.vn
}

\section{ARTICLE INFO ABSTRACT}

Article history:

Received:

16 Aug. 2014

Received in revised form:

01 July 2015

Accepted:

04 July 2015

Keywords:

Financial market

development, bank risk.
This paper examines how bank risk varies with change in financial market development through a dataset of 25 commercial banks in Vietnam. Empirical results show that the bank risk is positively associated with the development of Vietnam's financial market. Based on the research findings, we provide implications for commercial bank management and policy-making efforts. 


\section{Introduction}

A strand of research has indicated that financial market development has a positive impact on economic activities of a certain country through efficiently allocating capital sources to enterprises, facilitating risk management, scrutinizing business performance, and reducing costs of transferring resources (Levine, 1997; Merton, 1995). However, the development might also negatively influence banking institutions and the financial system, thus causing instability or even financial crisis (Demirguc-Kunt \& Detragiache, 1998).

Over the course of 20 years of reforming the financial system, Vietnam has seen a few preliminary achievements, one of which, most strikingly, is the rapid development of commercial banking system that allows the sector to well perform its financial mediation function in mobilizing and allocating capital resources in the economy (compared to other developing and transitional economies).

Figure 1 plots the variance in the indicators of Vietnam's banking system and stock market development, relative to those with low average income. Until end-2013 the rates of banking system development (BSD) and stock market development (SMD) calculated by credit to the private sector as a share of GDP and market capitalization as a share of GDP-were $96.8 \%$ and $32 \%$, whereas those recorded from low-income countries were $40.24 \%$ and $48.52 \%$, respectively.

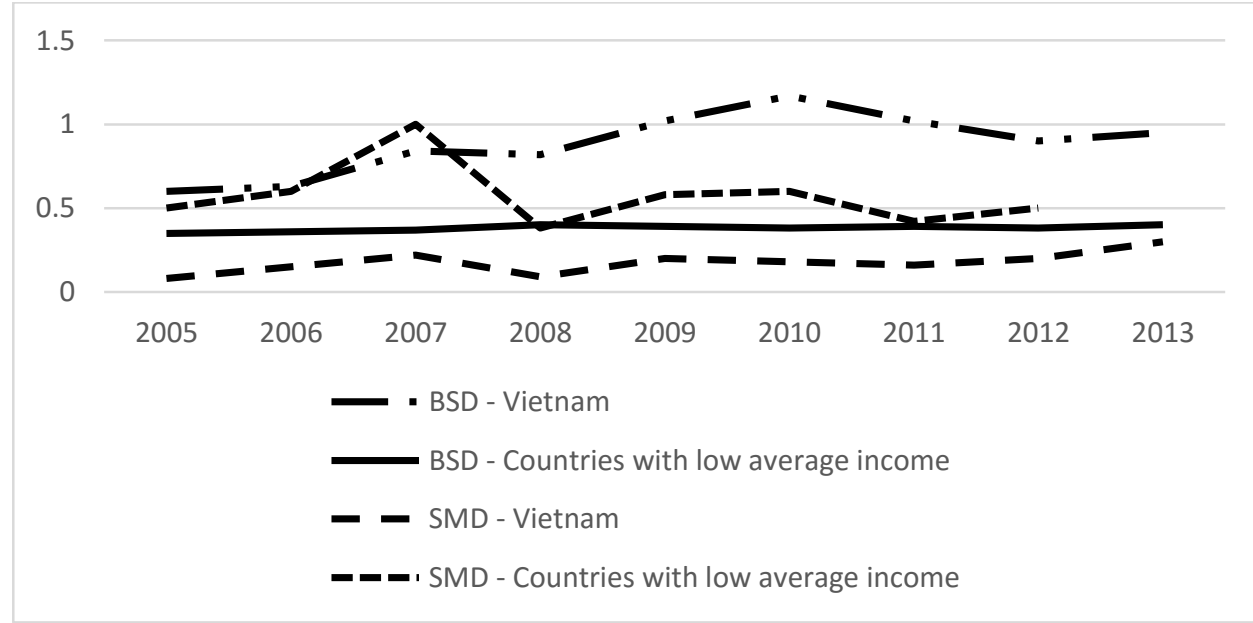

Figure 1. Development of banking system and stock market in several countries Source: WDI (World Bank, 2015) 
Overall, the Vietnam's banking system in particular and the financial system in general are still underdeveloped and are likely to be exposed to high levels of risk and instability. Before the 2007-2008 financial crisis there was a period of rapid development of the finance and banking system, which significantly contributed to economic growth. However, potential risks were also posed to the system, and under the shadow of economic uncertainties, it revealed a couple of downsides, including a sharp reduction in asset quality, soaring bad loans and assets, financial institutions' loss of confidence in businesses, and liquidity tension as incurred by a large number of credit institutions.

Much research has been carried out into financial development in Vietnam; nevertheless, the emphasis is mainly placed on its impact on economic growth and income inequality (Anwar \& Nguyen, 2011; Le \& Chu, 2015). This study, therefore, seeks to address the influence of financial market development on the risk of commercial banking institutions.

\section{Theoretical bases and methodology}

\subsection{Theoretical bases}

Demirgüç-Kunt and Maksimovic (1996) and Levine (1997) observed that financial market development impacts positively on real economic activities in an economy (investment, employment, productivity, economic growth, etc.). By efficient allocation of capital sources, financial intermediaries' performance is more effectual besides diminishing cost of capital, and also financial market in its development would better economic growth (Levine, 1997; Merton, 1995). Williams and Nguyen (2005) found that banking system liberalization in SEA countries enhances efficiency in its operation over the period between 1990 and 2003, and financial intermediaries (commercial banks) help lower financial barriers and boost firm investments. In an analysis of financial development, Ndikumana's (2005) study asserted that its positive effects on investment are not reliant on financial structure (the financial system is based on the banks themselves or equity capital), i.e. the financial structure is likely to exert no direct impact on investment.

In addition to its positive impact, a few studies highlighted the negative influence of financial development on banking institutions and financial system. Financial development may be conducive to increased instability within the financial system if 
financial intermediaries are involved in more risky activities, subject to a credit boom, which provokes a potential financial crisis. Ruiz-Porras (2009) believed that financial development would incur the increased risk of bank failures, whereas Festić et al. (2009) pinpointed the negative effect of credit growth on bank's asset quality (measured by nonperforming loans as a ratio to total assets).

From another perspective, Eichengreen and Arteta (2002) argued that financial liberalization encourages financial intermediaries to engage themselves in risky activities, thus increasing bank risk. Not only Demirgüç-Kunt and Detragiache (1998) but also Glick and Hutchison (1999) detected a positive relation between financial liberalization and bank risk. In accordance with Stiglitz's (2000) reasoning, financial liberalization process in emerging economies is a source of banking and/or financial crisis. Cubillas and González (2014), in investigating financial liberalization effects on risk of 4,333 banking institutions in 83 countries, ascribed the liberalization to increased bank risk-taking in both developed and developing nations.

Vithessonthi (2014b) confirmed the effect of financial development, which tends to increase risk (measured by banks' capital) of 52 banks in five SEA countries for the 1990-2012 period. In a similar study the author reasoned that development of financial market negatively relates to bank risk in Thailand. Stock market development has a tendency to reduce the risk, whereas banking sector development entails higher levels of instability via reduced capital yet increased beta coefficient of the bank.

Accordingly, there is extensive evidence, both theoretical and empirical, that financial development has certain effects on bank risk. This study, hence, is to investigate whether there exists such a nexus and/or impact.

\subsection{Data and methodology}

\subsubsection{Research data}

The dataset collated for this research includes audited financial statements of 25 commercial banks in Vietnam for the surveyed period between 2005 and 2013, featuring an unbalanced panel dataset with a total of 214 observations. A few indicators adopted in the present study are secondary data, measured using year end financial and annual statements of the banks. Particularly, the statistics on the macroeconomic situation are extracted from such sources as $\mathrm{WB}, \mathrm{ADB}$, and GSO. 


\subsubsection{Research model}

In light of the aforementioned theoretical bases, we propose the following model:

$$
\begin{aligned}
& y_{i t}=\alpha+\delta y_{i, t-1}+\beta_{1}(B S D)_{i t}+\beta_{2}\left(S M D_{i t}\right)+\beta_{3}(\text { Loan } / T A)_{i t}+\beta_{4}(C I R)_{i t}+ \\
& \beta_{5}(\text { Equity })_{i t}+\beta_{6}(H H I R D)_{i t}+\beta_{7}(\text { Size })_{i t}+\beta_{8}(R O E)_{i t}+\beta_{9}(G D P)_{i t}+ \\
& \beta_{10}(\text { INF })_{i t}+\varepsilon_{i t}
\end{aligned}
$$

where $y_{i t}$ is Zscore in natural logarithm (Laeven \& Levine, 2009; Demirgüc-Kunt \& Huizinga, 2010; Köhler, 2015). According to Köhler (2015), Zscore is an indicator of stability or risk of commercial banks; not only does it measure banks' credit risk but their liquidity and market risk pertaining to non-credit activities are also estimated using the index as follows:

$Z_{\text {score }}$ it $=\frac{R O A_{i t}+E Q T A_{i t}}{S_{R O A_{i p}}}$; where $E Q T A_{i t}$ is ratio of equity capital to total assets of bank $i$ at $t^{\text {th }}$ observation, and $S_{R O A_{i p}}$ is standard deviation of ROA of bank $i$ in surveyed period $p$. Zscore is negatively correlated with bank risk; the higher its value, the lower the bank risk (and, conversely, the lower its value, the higher the bank risk).

Also, we adopt Köhler's (2015) approach by which Zscore is represented by RAROA (risk-adjusted return on assets) and RACAR (risk-adjusted capital asset ratio), both of which are employed as dependent variables ${ }^{1}$ :

$$
\begin{aligned}
& R A R O A_{i t}=\frac{R O A_{i t}}{S_{D R O A_{i p}}} \\
& R A C A R_{i t}=\frac{E Q T A_{i t}}{S_{\text {DROA }}}
\end{aligned}
$$

For financial market development estimation, two measures are employed, including stock market development (Marketcapit) and banking sector development $\left(\mathrm{DCR}_{\mathrm{it}}\right)$ (Vithessonthi, 2014). While we compute the former using total market capitalization as a ratio to GDP, the latter is measured by the ratio of private credit from the banking system to GDP.

Besides the two measures of financial market development, we add to the model other control variables that proxy for bank internal factors, comprising loan-to-asset ratio (Loan/TA $\mathrm{Tit}_{\mathrm{it}}$ ), cost-income ratio $\left(\mathrm{CIR}_{\mathrm{it}}\right.$ ), equity-to-asset ratio (Equity ${ }_{\mathrm{it}}$ ), bank income diversification $\left(\mathrm{HHIRD}_{\mathrm{it}}\right)$, bank size (Size $\mathrm{it}_{\mathrm{it}}$ ), and return on equity $\left(\mathrm{ROE}_{\mathrm{it}}\right)$, and macro variables that affect bank risk, such as economic growth $\left(\mathrm{GDP}_{\mathrm{it}}\right)$ and inflation (INF $\mathrm{it}_{\mathrm{it}}$ ). The measurement of the variables and their expected signs are reported in Table 1. 
With a goal of measuring the impact of financial market development on risk of banking institutions, we aim to verify the following hypotheses:

$H_{1}$ : Financial market development impacts negatively on Zscore, meaning that $\beta_{1}$ and $\beta_{2}$ in Eq. 1 are negative. This implies that the development of financial market motivates banks to engage more in risky activities, causing instability of banking performance.

$H_{2}$ : Financial market development impacts positively on Zscore, meaning that $\beta_{1}$ and $\beta_{2}$ in Eq.1 are positive. This implies that the development of financial market increases stability of banking performance.

\section{Table 1}

Description of variables and expected signs

\begin{tabular}{|c|c|c|c|}
\hline Variable & Measured by & $\begin{array}{l}\text { Expected } \\
\text { sign }\end{array}$ & Source \\
\hline $\begin{array}{l}\text { Loan-to-asset ratio } \\
\left(\text { Loan/TA } \mathrm{TA}_{\mathrm{it}}\right)\end{array}$ & Loan/total assets & + & $\begin{array}{c}\text { Männasoo \& Mayes } \\
(2009)\end{array}$ \\
\hline $\begin{array}{l}\text { Cost-income ratio } \\
\left(\mathrm{CIR}_{\mathrm{it}}\right)\end{array}$ & Operating cost/operating income & - & $\begin{array}{c}\text { Männasoo \& Mayes } \\
(2009)\end{array}$ \\
\hline $\begin{array}{l}\text { Equity-to-asset ratio } \\
\text { (Equity }{ }_{\text {it }} \text { ) }\end{array}$ & Equity capital/total assets & $+/-$ & $\begin{array}{l}\text { Poghosyan \& Čihak } \\
\qquad(2011) ; \\
\text { Louzis et al. (2012) }\end{array}$ \\
\hline $\begin{array}{l}\text { Income } \\
\text { diversification } \\
\left(\text { HHIRD }_{\text {it }}\right)\end{array}$ & $\begin{array}{l}\text { HHIRD }=1-\left[\left(\frac{I N T}{T O R}\right)^{2}+\left(\frac{C O M}{T O R}\right)^{2}+\right. \\
\left.\left(\frac{T R A D}{T O R}\right)^{2}+\left(\frac{O T H}{T O R}\right)^{2}\right] ; \text { INT: interest } \\
\text { icome, COM: commissions and fees; } \\
\text { TRAD: trading income; OTH: other } \\
\text { income; TOR: total operating } \\
\text { revenue. }\end{array}$ & $+/-$ & $\begin{array}{l}\text { Mercieca et al. } \\
\text { (2007); Stiroh } \\
\text { (2004) }\end{array}$ \\
\hline Bank size $\left(\right.$ Size $\left._{i t}\right)$ & Log of total bank assets & $+/-$ & Louzis et al. (2012) \\
\hline $\begin{array}{l}\text { Return on equity } \\
\left(\mathrm{ROE}_{\mathrm{it}}\right)\end{array}$ & After-tax return/equity capital & - & $\begin{array}{c}\text { Poghosyan \& Čihak } \\
\text { (2011) }\end{array}$ \\
\hline
\end{tabular}




\begin{tabular}{llcr}
\hline Variable & Measured by & $\begin{array}{c}\text { Expected } \\
\text { sign }\end{array}$ & Source \\
\hline Growth $\left(\mathrm{GDP}_{\mathrm{it}}\right)$ & Annual GDP growth rate & - & $\begin{array}{c}\text { Uhde \& Heimeshoff } \\
(2009)\end{array}$ \\
Inflation $\left(\mathrm{INF}_{\mathrm{it}}\right)$ & Annual inflation rate & + & $\begin{array}{c}\text { Uhde \& Heimeshoff } \\
(2009)\end{array}$ \\
\hline
\end{tabular}

\subsubsection{Estimation techniques}

In this study the system GMM is employed. The approach was a modified version of Arellano and Bond (1991) by adding a few assumptions, based on the idea of using first differences along with the two-step estimation for more robustness (Windmeijer, 2005). In addition, we use the Windmeijer correction for the two-step estimation to avoid the problem of the error being smaller than the accepted value.

Bank internal variables are considered not completely exogeneous due to their potential two-way relation to bank risk (e.g., high ROE is associated with apparent high risk, causing banks to get involved in high-risk activities, and the opposite is true). In terms of risk impact, nevertheless, awareness of the current high risk drives banks to attempt risk reduction strategies, thus affecting ROE. The lag number of instrument variables in the study is restricted to 2 and 3 periods to ensure that their number is smaller than that of banks (25). Meanwhile, the macro variables such as GDP, inflation, BSD, and SMD are deemed exogenous.

Efficiency of the system GMM estimator is dependent on the validity of instrument variables. In light of such, we adopt two testing methods as proposed by Arellano and Bond (1991). Initially, the Sargan-Hansen test for overidentification allows us to verify whether there exists any correlation between instrument variables and residuals in the models. Theoretically, the two-step Hansen test is more robust than the one-step Sargan test (Roodman, 2006). Another important test for dynamic panel data is the second order autoregressive, or $\operatorname{AR}(2)$, for the residuals in Eq. 1.

\section{Research results and discussion}

\subsection{Descriptive statistics}

Table 2 presents descriptive statistics of the variables used in the regression model, all of which reveal the positive means and standard deviations. The Zscore of 
Vietnamese banks has a mean of 32.65, lower than both the average Zscore of Asian banks (41.78) (Soedarmono et al., 2011), and the average Zscore of banks in the Asian Pacific region (39.78) (Fu et al., 2014). This suggests that the banking institutions in Vietnam face a higher level of risk than those in regional countries.

For the 2005-2013 period the average ratio of equity capital to total assets reaches $10.5 \%$, which fundamentally reflects a certain level of adequacy and safety regarding commercial banks' performance. Additionally, the average ROE, loan/total assets, and CIR are found to reach $10.9 \%, 52.3 \%$, and $44.4 \%$ respectively.

Given the indicators of financial market development, the banking system development (BSD) measured by the ratio of credit to the private sector to GDP has a mean of approximately $90 \%$ from its highest and lowest values of about $115 \%$ and $60.5 \%$ respectively, whereas the average, highest, and lowest values of stock market development (SMD) measured by the ratio of market capitalization to GDP are $17.8 \%$, $32 \%$, and $7.1 \%$ respectively.

\section{Table 2}

Results of descriptive statistics of variables

\begin{tabular}{llllll}
\hline & Obs. & Mean & Std. dev. & Min & Max \\
\hline Zscore & 214 & 32.65 & 14.56 & 8.29 & 82.04 \\
Loan/TA & 214 & 0.523 & 0.134 & 0.194 & 0.880 \\
CIR & 214 & 0.444 & 0.124 & 0.207 & 0.776 \\
EQUITY & 214 & 0.105 & 0.040 & 0.043 & 0.205 \\
HHIRD & 214 & 0.350 & 0.135 & 0.028 & 0.648 \\
SIZE & 214 & 7.525 & 0.650 & 5.544 & 8.761 \\
ROE & 214 & 0.109 & 0.059 & 0.001 & 0.306 \\
GDP & 214 & 0.062 & 0.008 & 0.052 & 0.075 \\
INF & 214 & 0.112 & 0.049 & 0.060 & 0.199 \\
BSD & 214 & 0.899 & 0.167 & 0.605 & 1.147 \\
SMD & 214 & 0.178 & 0.071 & 0.080 & 0.320 \\
\hline
\end{tabular}




\subsection{Discussion}

Table 3 reports the estimated results of Eq. 1. The positive and significant regression

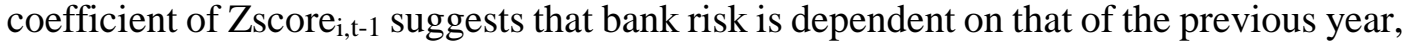
which demonstrates the dynamism of the research model. Therefore, the estimation techniques in use are suitable for the research sample. A few implications can be drawn from Table 3 as follows:

Banking system development (BSD) and stock market development (SMD) have negative effects on Zscore of banks; that is, they increase bank instability or risk. This result supports the findings by Kölhler (2014) and Cubillas and González (2014), merely due to the fact that the process of financial liberalization in Vietnam, over the past years, has triggered 'smooth' credit growth, and excessive credit supply has provoked speculative behaviors in stock and realty investments. Indeed, Dinh et al. (2010) documented the "leakage" of loans for economic stabilization in 2009 into property markets, especially the stock market. Thus, bank credit growth, accompanied by stock market growth from speculative activities, has led to increased risk of the banking system. The estimated results in Columns 2 and 3 (Table 3) indicate that financial development has a negative and significant impact on RACAR, whereas its effect on RAROA is not statistically significant. This implies that the effect of financial market development on bank risk in Vietnam is mainly observed via its influence on the capital adequacy ratio.

Concerning the asset structure (Loan/TA), the fact that its coefficient is positively associated with Zscore implies that it reduces risk of commercial banks. This result suggests that increase in lendings enables the implementation of loan porfolios, subject to diminishing bank income fluctuations and therefore lower bank risk (Uhde \& Heimeshoff, 2009).

Given the equity-to-asset ratio (EQUITY), it appears to positively relate to Zscore, implying that the more equity a bank acquires, the safer it will be.

Bank size (SIZE) has a positive association with Zscore (i.e. reduced risk), which is in line with Louzis et al.'s (2012) reasoning that large-scaled banks would be more likely to implement diversification and therefore would face lower risk levels. This can be attributed to advanced technological investment for risk management as having been adopted by big banks in Vietnam. 
Regarding the impact of return on equity (ROE) on bank risk, it is suggested that the former is negatively related to Zscore, i.e. increasing bank risk, in constrast with previous findings (Uhde \& Heimeshoff, 2009; Cubillas \& González, 2014). This can be explained by the tradeoffs between risk and return. A sharp difference, over the past time, has been recorded in terms of lending rates and deposit rates among Vietnam's banking institutions, especially thanks to the policy on interest rate cap implemented by $\mathrm{SBV}$, but actually, there has not been a high rise in interest rates since most banks insufficiently adopt loan loss provision practices. Moreover, high lending rates do reversely affect and increase non-performing loans and/or bank risk as the customer cannot make timely repayment of both principal and interest.

Economic growth (GDP) is positively related to Zscore (reducing bank risk), consistent with relevant findings by Poghosyan and Čihak (2011) and Cubillas and González (2014). This result demonstrates that bank risk occurs cyclically.

Cost-income ratio (CIR) and income diversification (HHIRD) seem not to be associated with bank risk, and nor does a relation exist between inflation (INF) and bank risk.

After re-regressing Eq. 1 with the use of RAROA and RACAR as two dependent variables, we find that the impacts of explanatory variables have consistent signs and are statistically significant in the interaction between Zscore and RACAR. This implies that the effects produced on bank risk are mainly through risk-adjusted capital asset ratio (RACAR).

The Hansen test results with p-value $>0.05$ (Columns 1 and 3 ) indicate the suitability of instrument variables used in the model. Furthermore, the Arellano-Bond test results on autocorrelation of residuals with p-value $>0.05$ (test for $\mathrm{AR}(2)$ ) suggest that there is no existence of second-order serial correlations among the residuals in Eq. 1.

\section{Table 3}

Estimated results

\begin{tabular}{|c|c|c|c|c|c|c|}
\hline \multirow[b]{2}{*}{ Variable } & \multicolumn{2}{|l|}{$\begin{array}{l}\text { Zscore } \\
\text { (1) }\end{array}$} & \multicolumn{2}{|c|}{$\begin{array}{c}\text { RACAR } \\
\text { (2) }\end{array}$} & \multicolumn{2}{|c|}{$\begin{array}{c}\text { RAROA } \\
\text { (3) }\end{array}$} \\
\hline & Regression coef. & $\begin{array}{l}\text { Std. } \\
\text { error }\end{array}$ & $\begin{array}{c}\text { Regression } \\
\text { coef. }\end{array}$ & $\begin{array}{l}\text { Std. } \\
\text { error }\end{array}$ & $\begin{array}{l}\text { Regression } \\
\text { coef. }\end{array}$ & $\begin{array}{l}\text { Std. } \\
\text { error }\end{array}$ \\
\hline
\end{tabular}

Zscore $_{\mathrm{i}, \mathrm{t}-1}$

$0.3347^{* * *} \quad 0.0646$ 


\begin{tabular}{|c|c|c|c|c|c|c|}
\hline \multirow[b]{2}{*}{ Variable } & \multicolumn{2}{|l|}{$\begin{array}{l}\text { Zscore } \\
\text { (1) }\end{array}$} & \multicolumn{2}{|c|}{$\begin{array}{c}\text { RACAR } \\
\text { (2) }\end{array}$} & \multicolumn{2}{|c|}{$\begin{array}{c}\text { RAROA } \\
\text { (3) }\end{array}$} \\
\hline & Regression coef. & $\begin{array}{l}\text { Std. } \\
\text { error }\end{array}$ & $\begin{array}{l}\text { Regression } \\
\text { coef. }\end{array}$ & $\begin{array}{l}\text { Std. } \\
\text { error }\end{array}$ & $\begin{array}{l}\text { Regression } \\
\text { coef. }\end{array}$ & $\begin{array}{l}\text { Std. } \\
\text { error }\end{array}$ \\
\hline RACAR $_{\mathrm{i}, \mathrm{t}-1}$ & & & $0.2581^{* * *}$ & $(0.0549)$ & & \\
\hline RAROA $_{\mathrm{i}, \mathrm{t}-1}$ & & & & & $0.2186^{* * *}$ & 0.0603 \\
\hline Loan/TA & $0.9599^{* * * *}$ & 0.1651 & $0.9407^{* * *}$ & $(0.1806)$ & 1.1848 & 1.0400 \\
\hline CIR & -0.1062 & 0.1933 & -0.0471 & $(0.1790)$ & $-2.9272^{* * *}$ & 0.7202 \\
\hline EQUITY & $6.3741^{* * *}$ & 0.8935 & $7.4885^{* * *}$ & $(0.8088)$ & -0.4803 & 1.9706 \\
\hline HHIRD & 0.3237 & 0.2015 & 0.2812 & $(0.1832)$ & -0.0510 & 0.5820 \\
\hline SIZE & $0.3172^{* * *}$ & 0.0595 & $0.3202^{* * *}$ & $(0.0630)$ & 0.1927 & 0.1958 \\
\hline ROE & $-1.0372^{* * *}$ & 0.3179 & $-1.3925^{* * *}$ & $(0.3160)$ & $2.9500^{* * *}$ & 0.9309 \\
\hline GDP & $4.8663^{* *}$ & 2.0482 & $4.7394^{* *}$ & $(1.8017)$ & -4.0303 & 10.296 \\
\hline INF & -0.1496 & 0.1795 & -0.0853 & $(0.1708)$ & 0.7043 & 0.9252 \\
\hline BSD & $-0.2427^{*}$ & 0.1189 & $-0.2528^{* *}$ & $(0.1158)$ & -0.1301 & 0.2175 \\
\hline SMD & $-0,6912^{* * *}$ & 0,1640 & $-0,5759^{* * *}$ & $(0,1589)$ & $-0,7350$ & 0,5347 \\
\hline No. of observations & 189 & & 189 & & 189 & \\
\hline Test for AR(1) (p-value) & 0.012 & & 0.016 & & 0.081 & \\
\hline Test for $\operatorname{AR}(2)$ (p-value) & 0.665 & & 0.585 & & 0.693 & \\
\hline Hansen test (p-value) & 0.787 & & 0.784 & & 0.698 & \\
\hline Windmeijer Correction & Yes & & Yes & & Yes & \\
\hline No. of instruments & 24 & & 24 & & 24 & \\
\hline
\end{tabular}

Note: $*, * *$, and $* * *$ denote significance levels of $10 \%, 5 \%$, and $1 \%$ respectively.

\section{Conclusion and implications}

\subsection{Conclusion}

It is suggested by the empirical results obtained in this study that financial market development in Vietnam has a tendency to increase bank risk, whereas bank internal 
factors, such as asset structure, capital adequacy, and bank size are found to reduce it. Profitability, nevertheless, tends to be leading to higher risk, which hints that commercial banks are more likely to get involved in high-risk activities in search of higher returns. In terms of effects of macro factors on bank risk, the results of regression analysis demonstrate a negative relation between growth and risk, i.e. bank performance is cyclically affected. Additionally, no correlations are detected between banking efficiciency, the level of income diversification, and inflation rate and bank risk.

\subsection{Policy implications}

In light of the suggested results, we put forward some implications with regard to management of commercial banks and macro economy.

Concerning management of commercial banking institutions:

Since bank risk is suggested to be reduced by internal factors, such as asset structure, capital adequacy, and size, it is necessary for commercial banks to improve their financial capacity to withstand various shocks posing risks to their performance by enhancing the quality of loans on the basis of revising credit policy and risk management strategies and restructuring equity capital.

The fact that bank profitability is subject to higher risk levels implies that Vietnam's banking institutions would willingly face risk in their seeking higher returns. Thus, a timely re-adjustment in policies on credit activities and risk managment is essential to banking administration.

CIR is adversely correlated with bank risk, which is, however, not statistically significance. According to the "skimping" theory of Louzis et al. (2012), there will be trade-offs between resource allocation for loan offerings and/or monitoring and cost reduction. This means that if banks cut costs relating to enforcing the credit quality, it will then be conducive to increasing non-performing loans in the long run. In the context of current reduction practices as followed by Vietnamese banks, consideration must be given to rational cost cutting without affecting the efficiency of banks' risk management.

Inflation is shown to positively relate to bank risk, albeit not statistically significant. Yet, Uhde and Heimeshoff (2009) observed that the inflation impact depends on whether banks' prediction of inflation rates is capable or not. The emphasis, therefore, should be placed on the quality of inflation anticipation to minimize risk levels in banking performance. 


\section{Concerning macroeconomic management:}

Economic growth and bank risk are in close association; thus, in the course of macroeconomic stabilization, lower credit growth levels should be legally preferred as it may underpin the stabilized banking system.

It is also indicated that financial market development tends to give rise to banking operation instability. As a result, the quality of stock market and banking system development should be underscored in the process of financial development

\section{Note}

${ }^{1}$ The two variables carry similar implications to Zscore: the higher their values, the lower the risk.

\section{References}

Anward, S., \& Nguyen, L. P. (2011). Financial development and economic growth in Vietnam. Journal of Economics and Finance, 35(3), 348-360.

Arellano, M., \& Bond, S. (1991). Some tests of specification for panel data: Monte Carlo evidence and an application to employment equations. The Review of Economic Studies, 58(2), 277-297.

Cubillas, E., \& González, F. (2014). Financial liberalization and bank risk-taking: International evidence. Journal of Financial Stability, 11, 32-48.

Demirguc-Kunt, A., \& Detragiache, E. (1998). Financial liberalization and financial fragility (IMF Working Paper No. 98/83). Washington, DC: International Monetary Fund.

Demirgüc-Kunt, A., \& Huizinga, H. (2010). Bank activity and funding strategies: The impact on risk and returns. Journal of Financial Economics, 98(3), 626-650.

Demirgüç-Kunt, A., \& Maksimovic, V. (1996). Stock market development and financing choices of firms. The World Bank Economic Review, 10(2), 341-369.

Dinh, T. M., To, T. T., Malesky, M., \& Nguyen, D. T. (2010). Impact of interest rate support policy on business operation (in Vietnamese) (Research Paper No. 20). Hanoi, Vietnam: Vietnam Institute for Economic and Policy Research.

Eichengreen, B., \& Arteta, C. (2002). Banking crises in emerging markets: Presumptions and evidence. In M. Skreb \& I. Blejer (eds.), Financial policies in emerging markets. Cambridge, MA: MIT Press.

Festić, M., Kavkler, A., \& Repina, S. (2011). The macroeconomic sources of systemic risk in the banking sectors of five new EU member states. Journal of Banking \& Finance, 35(2), 310-322.

Fu, X., Lin, Y., \& Molyneux, P. (2014). Bank competition and financial stability in Asia Pacific. Journal of Banking \& Finance, 38, 64-77. doi:10.1016/j.jbankfin.2013.09.012 
Glick, R., \& Hutchison, M. (1999). Banking and currency crises: How common are twins (Working Paper Pb99-07). San Francisco, CA: Federal Reserve Bank of San Francisco.

Köhler, M. (2015). Which banks are more risky? The impact of business model on bank stability. Journal of Financial Stability, 16, 195-212.

Laeven, L., \& Levine, R. (2009). Bank governance, regulation and risk taking. Journal of Financial Economics, 93(2), 259-275.

Le, Q. H., \& Chu, M. H. (2015). Impact of financial development on income inequality in Vietnam (in Vietnamese). Journal of Economic Development, 26(8), 2-17.

Levine, R. (1997). Financial development and economic growth: Views and agenda. Journal of Economic Literature, XXXV, 688-726.

Louzis, D. P., Vouldis, A. T., \& Metaxas, V. L. (2012). Macroeconomic and bank-specific determinants of non-performing loans in Greece: A comparative study of mortgage, business and consumer loan portfolios. Journal of Banking \& Finance, 36(4), 1012-1027.

Männasoo, K., \& Mayes, D. G. (2009). Explaining bank distress in Eastern European transition economies. Journal of Banking and Finance, 33(2), 244-253.

Mercieca, S., Schaeck, K., \& Wolfe, S. (2007). Small European banks: Benefits from diversification? Journal of Banking and Finance, 31(7), 1975-1998.

Merton, R. C. (1995). A functional perspective of financial intermediation. Financial Management, 24(2), 23-41.

Ndikumana, L. (2005). Financial development, financial structure, and domestic investment: International evidence. Journal of International Money and Finance, 24(4), 651-673.

Poghosyan, T., \& Čihak, M. (2011). Determinants of bank distress in Europe: Evidence from a new data set. Journal of Financial Services Research, 40, 163-184.

Roodman, D. (2006). How to do xtabond2: An introduction to "difference" and "system" GMM in Stata (Working Paper Number 103). Washington, DC: Center for Global Development.

Ruiz-Porras, A. (2009). Financial structure, financial development and banking fragility: International evidence. Análisis Económico, 24(56), 147-173.

Soedarmono, W., Machrouh, F., \& Tarazi, A (2011). Bank market power, economic growth and financial stability: Evidence from Asian banks. Journal of Asian Economics, 22, 460-470.

Stiglitz, J. E. (2000). Capital market liberalization, economic growth, and instability. World Development, 28, 1075-1086.

Stiroh, K. J. (2004). Diversification in banking: Is noninterest income the answer? Journal of Money, Credit, and Banking, 36(5), 853-882.

Uhde, A., \& Heimeshoff, U. (2009). Consolidation in banking and financial stability in Europe: Empirical evidence. Journal of Banking and Finance, 33(7), 1299-1311. 
Vithessonthi, C. (2014). The effect of financial markets development on bank risk: Evidence from Southeast Asian countries. International Review of Financial Analysis, 35(2014), 249-260.

Williams, J., \& Nguyen, N. (2005). Financial liberalisation, crisis, and restructuring: A comparative study of bank performance and bank governance in South East Asia. Journal of Banking \& Finance, 29(8-9), 2119-2154.

Windmeijer, F. (2005). A finite sample correction for the variance of linear efficient two-step GMM estimators. Journal of Econometrics, 126(1), 25-51. 